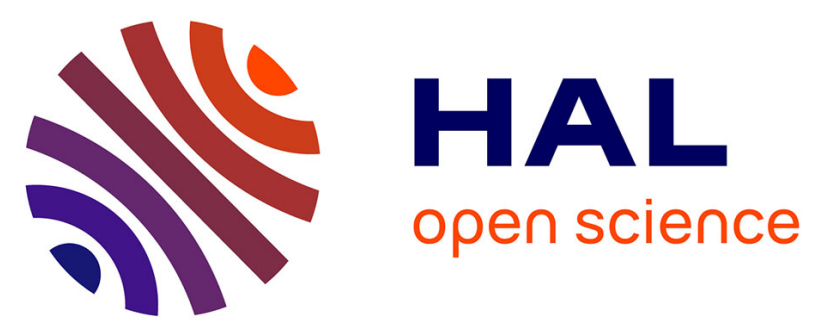

\title{
Compositional mapping of Titan's surface using Cassini VIMS and RADAR data
}

\author{
Anezina Solomonidou, Athena Coustenis, Alice Le Gall, Rosaly Lopes, \\ Michael Malaska, Bernard Schmidtt, Kenneth Lawrence, Charles Elachi, \\ Ashley Schoenfeld, Christophe Sotin, et al.
}

\section{To cite this version:}

Anezina Solomonidou, Athena Coustenis, Alice Le Gall, Rosaly Lopes, Michael Malaska, et al.. Compositional mapping of Titan's surface using Cassini VIMS and RADAR data. European Planetary Science Congress. EPSC 2021, Sep 2021, Virtual Meeting, France. 10.5194/epsc2021-137 . insu03311384

\section{HAL Id: insu-03311384 \\ https://hal-insu.archives-ouvertes.fr/insu-03311384}

Submitted on 31 Jul 2021

HAL is a multi-disciplinary open access archive for the deposit and dissemination of scientific research documents, whether they are published or not. The documents may come from teaching and research institutions in France or abroad, or from public or private research centers.
L'archive ouverte pluridisciplinaire HAL, est destinée au dépôt et à la diffusion de documents scientifiques de niveau recherche, publiés ou non, émanant des établissements d'enseignement et de recherche français ou étrangers, des laboratoires publics ou privés. 
EPSC Abstracts

Vol. 15, EPSC2021-137, 2021, updated on 30 Jul 2021

https://doi.org/10.5194/epsc2021-137

European Planetary Science Congress 2021

(C) Author(s) 2021. This work is distributed under

the Creative Commons Attribution 4.0 License.

\title{
Compositional mapping of Titan's surface using Cassini VIMS and RADAR data
}

\author{
Anezina Solomonidou ${ }^{1,2,3}$, Athena Coustenis ${ }^{2}$, Alice Le Gall ${ }^{4}$, Rosaly Lopes ${ }^{5}$, Michael Malaska ${ }^{5}$, \\ Bernard Schmidttt ${ }^{6}$, Kenneth Lawrence ${ }^{5}$, Charles Elachi ${ }^{1}$, Ashley Schoenfeld ${ }^{7}$, Christophe Sotin ${ }^{8}$, \\ Stephen Wall ${ }^{1}$, Yannis Markonis ${ }^{3}$, and Christos Matsoukas ${ }^{9}$ \\ ${ }^{1}$ California Institute of Technology (Caltech), Los Angeles, United States of America (anezina.solomonidou@jpl.nasa.gov) \\ ${ }^{2}$ LESIA-Observatoire de Paris, CNRS, UPMC Univ., Paris 06, Univ. Paris-Diderot, Meudon, France \\ ${ }^{3}$ Faculty of Environmental Sciences, Czech University of Life Sciences Prague, Suchdol, Praha, Czech Republic \\ ${ }^{4}$ LATMOS/IPSL, UVSQ Université Paris-Saclay, Sorbonne Université, CNRS, Guyancourt, France \\ ${ }^{5}$ Jet Propulsion Laboratory, California Institute of Technology, Pasadena, California, USA \\ ${ }^{6}$ Institut de Planétologie et d'Astrophysique de Grenoble, Université Grenoble Alpes, CNRS, Grenoble, France \\ ${ }^{7}$ Department of Earth, Planetary, and Space Sciences, University of Calilfornia, Los Angeles, CA, USA \\ ${ }^{8}$ Laboratoire Planétologie et Géodynamique, LPGNantes, CNRS UMR 6112, Université de Nantes, Nantes, France \\ ${ }^{9} \mathrm{KTH}-$ Royal Institute of Technology, Stockholm, Sweden
}

The investigation of Titan's surface chemical composition is of great importance for the understanding of the atmosphere-surface-interior system of the moon. The Cassini cameras and especially the Visual and infrared Mapping Spectrometer has provided a sequence of spectra showing the diversity of Titan's surface spectrum from flybys performed during the 13 years of Cassini's operation. In the 0.8-5.2 $\mu \mathrm{m}$ range, this spectro-imaging data showed that the surface consists of a multivariable geological terrain hosting complex geological processes. The data from the seven narrow methane spectral "windows" centered at $0.93,1.08,1.27,1.59,2.03,2.8$ and 5 $\mu \mathrm{m}$ provide some information on the lower atmospheric context and the surface parameters. Nevertheless, atmospheric scattering and absorption need to be clearly evaluated before we can extract the surface properties. In various studies (Solomonidou et al., 2014; 2016; 2018; 2019; 2020a, 2020b; Lopes et al., 2016; Malaska et al., 2016; 2020), we used radiative transfer modeling in order to evaluate the atmospheric scattering and absorption and securely extract the surface albedo of multiple Titan areas including the major geomorphological units. We also investigated the morphological and microwave characteristics of these features using Cassini RADAR data in their SAR and radiometry mode. Here, we present a global map for Titan's surface showing the chemical composition constraints for the various units. The results show that Titan's surface composition, at the depths detected by VIMS, has significant latitudinal dependence, with its equator being dominated by organic materials from the atmosphere and a very dark unknown material, while higher latitudes contain more water ice. The albedo differences and similarities among the various geomorphological units give insights on the geological processes affecting Titan's surface and, by implication, its interior. We discuss our results in terms of origin and evolution theories.

References: [1] Solomonidou, A., et al. (2014), J. Geophys. Res. Planets, 119, 1729; [2] Solomonidou, A., et al. (2016), Icarus, 270, 85; [3] Solomonidou, A., et al. (2018), J. Geophys. Res. Planets, 123, 489; [4] Solomonidou, A., et al. (2020a), Icarus, 344, 113338; [5] Solomonidou, 
A., et al. (2020b), A\&A 641, A16; [6] Lopes, R., et al. (2016) Icarus, 270, 162; [7] Malaska, M., et al. (2016), Icarus 270, 130; [8] Malaska, M., et al. (2020), Icarus, 344, 113764.

Acknowledgements: This work was conducted at the California Institute of Technology (Caltech) under contract with NASA. Y.M. and A.S. (partly) was supported by the Czech Science Foundation (grant no. 20-27624Y). (C2021 California Institute of Technology. Government sponsorship acknowledged. 